\title{
Maternal and Neonatal Characteristics of Umbilical Cord Blood Units from the Polish Public Stem Cell Bank of the Regional Science and Technology Center
}

\author{
Nowakowski $\mathbf{P}^{1^{*}}$, Laskowski $\mathbf{M}^{2}$, Niebudek $\mathbf{K}^{1}$, Lorens $\mathbf{J}^{1}$, Glenska-Olender $\mathbf{J}^{1}$ and Witon $\mathbf{M}^{3}$ \\ ${ }^{1}$ Department of Stem Cell Banking, The Regional Science and Technology Center, Podzamcze 45, 26-060 Checiny, Poland \\ ${ }^{2}$ Medical Diagnostic Laboratory, The Regional Science and Technology Center, Podzamcze 45, 26-060 Checiny, Poland \\ ${ }^{3}$ Department of Biobanking and Scientific Research, The Regional Science and Technology Center, Podzamcze 45, 26-060 Checiny, Poland
}

*Corresponding author: Nowakowski P, Department of Stem Cell Banking, The Regional Science and Technology Center, Podzamcze 45, 26-060 Chęciny, Poland, Tel: ++48 4134340 50; E-mail: piotr.nowakowski@rcnt.pl

Received date: Jul 25, 2015, Accepted date: Sep 07, 2015, Publication date: Sep 11, 2015

Copyright: (c) 2015 Nowakowski P, et al. This is an open-access article distributed under the terms of the Creative Commons Attribution License, which permits unrestricted use, distribution, and reproduction in any medium, provided the original author and source are credited.

\begin{abstract}
Objective: Cord blood comes from a newborn's umbilical cord and can be collected immediately after birth in a non-invasive and painless way. Umbilical cord blood was evaluated as alternate and very useful source of powerful stem cells. The usefulness of umbilical cord blood for transplantation is limited by the variable and often small amount of cord blood obtained from patients. The aim of this study was to examine maternal (gestational age, mode of delivery) and neonatal (birth weight, sex, mode of delivery, $\mathrm{ABO}$ and $\mathrm{RhD}$ blood types of neonates) factors affecting quantity and quality of CD34+ cells and determine correlations between them.
\end{abstract}

Methods: A total of 189 umbilical cord blood (UCB) units donated to the Public Stem Cell Bank (Poland) were evaluated. After UCB processing, white blood cell count, the type of blood group, CD34+ cell count and percentage were determined. Differences were considered to be statistically significant when the $p$ value was less than 0.05 .

Results: Positive correlation $(r=0.273, p<0.05)$ between sex of the neonate and birth weight was reported. There is also correlation between sex and CD34+ cell number $(r=0.187, p<0.05)$ as well as between sex and percentage of CD34+ cells $(r=0.229, p<0.05)$. Furthermore, there is no correlation between gestational age and CD34+ cell number as well as between gestational age and percentage of CD34+ cells. Statistical analysis showed there is no relationship between blood group $(\mathrm{ABO}$ and $\mathrm{RhD})$ and count of $\mathrm{CD} 34+$ cells.

Conclusion: Our results suggest that sex/blood group typing is not useful for assessing whether future collected umbilical cord blood will possess greater or lower therapeutic potential, however it is necessary to perform the studies on larger population.

Keywords: Umbilical cord blood; Public cord blood bank; Stem cells; CD34+ cells; Blood type; Neonatal factors; Maternal factors

\begin{abstract}
Abbreviations:
3-Diff: 3-Part Differential; 7-AAD: 7-Aminoactinomycin D; BC: Buffy Coat; CD34: Hematopoietic Progenitor Cell Antigen CD34; CD34+: Hematopoietic Progenitor Cell Antigen CD34 Positive; CD45: Leukocyte Common Antigen CD45; CD45+: Leukocyte Common Antigen CD45 Positive; CPD: Citrate Phosphate Dextrose; FITC: Fluorescein Iothiocyanate; PE: Phycoerythrin; RhD: Rh Blood Group System, D Antigen; UCB: Umbilical Cord Blood; $\mathrm{V}_{0}$ : Total Volume of Collected Umbilical Cord Blood Unit without CPD; $\mathrm{V}_{1}$ : Total Volume of Umbilical Cord Blood Unit with CPD; WBC: White Blood Cells; $\mathrm{WBC}_{0}$ : Total Number of White Blood Cells in Umbilical Cord Blood Unit without CPD; $\mathrm{WBC}_{1}$ : The Total Number of White Blood Cells in the Umbilical Cord Blood Unit with CPD
\end{abstract}

\section{Introduction}

The morbidity and mortality associated with allogenic bone marrow transplantation is still high so it is necessary to find alternate sources of powerful stem cells. Among those alternate sources, umbilical cord blood and placental blood were evaluated as very useful. Umbilical cord blood has now been established as a source of stem cells for transplant for patients suffering from various diseases. The successful engraftment of transplanted cells depends on both, the quality and quantity of stem cells. It is very important to obtain big amount of good quality umbilical cord blood. The usefulness of the umbilical cord blood for transplantation is limited by the variable and often small amount of cord blood obtained from patients [1]. Current data suggest that umbilical cord blood is an acceptable source of transplantable hematopoietic stem cells, at least in recipient $<40 \mathrm{~kg}$ [2].

Before the usefulness of cord blood in medicine was found, the umbilical cord was treated as medical waste and was disposed. Today we can store it long term without losing its greatest value which are stem cells. Collection of umbilical cord blood is safe and painless. The procedure is short and non-invasive. It takes place right after child's birth and does not threaten mothers or child's life or health. The blood may be collected during natural labor as well as cesarean section.

The usefulness of cord blood contributed to creating stem cells banks, both private and public. The project of creating the Public Stem Cell Bank in Podzamcze in Poland is a response to the resolution of the European Parliament which invites to donate tissues and cells 
Citation: Nowakowski P, Laskowski M, Niebudek K, Lorens J, Glenska-Olender J, et al. (2015) Maternal and Neonatal Characteristics of Umbilical Cord Blood Units from the Polish Public Stem Cell Bank of the Regional Science and Technology Center. J Blood Disord Transfus 6: 306. doi:10.4172/2155-9864.1000306

Page 2 of 6

voluntarily and freely of charge, in order to facilitate finding compatible donor across Europe and to help saving lives. It will enable inhabitants of the Swietokrzyskie Voivodeship to donate umbilical cord blood in order to enrich the pool of stem cells available for unrelated recipients as well as enable our scientific staff to study biological factors affecting stem cells in this valuable source.

Cord blood comes from a newborn's umbilical cord and can be collected immediately after birth. It contains powerful stem cells that are used to regenerate immune system. In cord blood transplantation the total number of CD34+ cells is crucial for long-term survival. Many studies have been reported regarding the maternal and neonatal factors that can affect quality and quantity of CD34+ stem cells.

In this study we focused on cord blood from 189-single birth term deliveries (Polish neonates from Swietokrzyskie Voivodeship). Furthermore, we investigated the influence of some of the maternal and neonatal factors on selected parameters of cord blood. We hope that results of this study will allow us to determine and examine maternal and neonatal factors affecting quantity and quality of CD34+ cells.

\section{Materials and Methods}

\section{Collection}

A total of 189 umbilical cord blood (UCB) units donated to the Public Stem Cell Bank (Poland) from December 2014 to July 2015 were evaluated. UCB was collected by midwifes in hospital after childbirth and placenta delivery. Procedure of UCB collection is completely noninvasive, does not endanger health of the mother or child. The midwifes collected UCB into a sterile single use kit (BioMed Consulting \& Training, Poland). The maximum volume of collection bag was $200 \mathrm{ml}$. Collection bag contained $21 \mathrm{ml}$ of anticoagulant CPD, and there was $8 \mathrm{ml}$ of CPD in an additional bag to flush the drain after collection. Along with the UCB collection kit, medical records which contained information about child's sex and weight as well as duration of pregnancy were provided. Parents signed the documents in which they have agreed to organize and coordinate the collection, transport, processing and storage of cord blood stem cells, and thereby they have waived their rights to the blood. If the collected cord blood or conditions of preparation for objective reasons do not meet the criteria required to continue its use for the purpose of transplantation, parents have consented to the use of the blood for testing and research related to the development of science of cord blood and stem cells at the discretion of the Bank's employees.

\section{Transport}

UCB was transported to the Public Bank at temperature range between 10 and $30^{\circ} \mathrm{C}$. Time between collection and end of freezing of prepared UCB units did not exceed 48 hours.

\section{UCB processing}

Blood qualified for the preparation had to meet the following conditions: $\mathrm{WBC}_{1} \geq 8.0 \times 10^{6} / \mathrm{ml}$; minimal volume of cord blood without anticoagulant: $40 \mathrm{ml}$. The volume of UCB was calculated using the density factor of $1.06 \mathrm{~g} / \mathrm{ml}$.

Before volume reduction by UCB protocol on Sepax 2, $0.5 \mathrm{ml}$ of blood sample was taken to determine $\mathrm{WBC}_{1}$ count. Collection bag was connected to the single use kit Sepax CS-570.4 (Biosafe SA,
Switzerland). Umbilical cord blood was processed using Sepax 2. This cell processing system uses a rotating syringe technology that provides both separation through rotation of the syringe chamber and component transfer through displacement of the syringe piston (Figure $1)$.

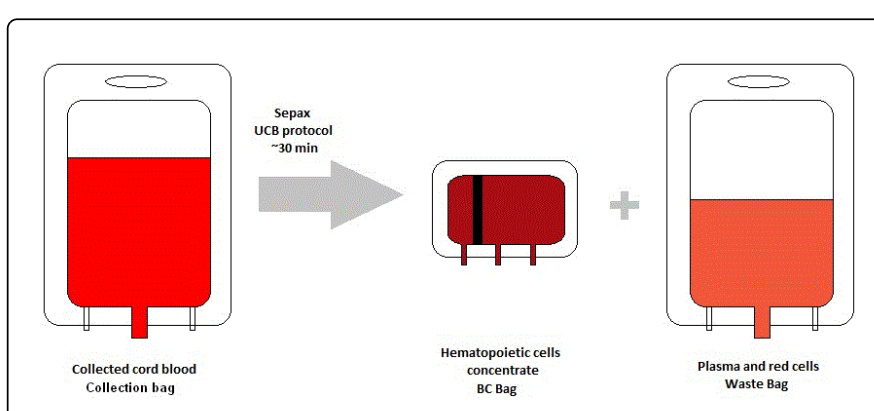

Figure 1: Processing of UCB by Sepax 2.

After the separation process the majority of plasma and red blood cells were transferred back into the collection bag (waste bag). A mixture of plasma and erythrocytes constituted material for blood type determination. From the BC (buffy coat) bag, containing the haematopoietic cells concentrate, a sample of $0.5 \mathrm{ml}$ was taken to determine a number of CD34+ cells.

\section{White blood cell count}

A total white blood cells count (WBC1) was measured with 3-Diff hematology analyzer (Mindray BC-2800, Shenzhen, China) using reagents recommended by manufacturer. The material for the examination was umbilical cord blood with CPD anticoagulant $\left(\mathrm{WBC}_{1}\right)$. Collected material, in every case, has a different volume ratio of anticoagulant to umbilical cord blood (constant volume of CPD, variable volume of UCB). According to the letter from Dr. Rabinovitch, published in October 2009 [3], to the Editor of article, Reference ranges for umbilical cord blood hematological values", published in July 2009 [4], we have decided to calculate the total number of white blood cells in blood circulating in the umbilical cord $\left(\mathrm{WBC}_{0}\right)$ according to the following formula:

$\left(\mathrm{WBC}_{1} \times \mathrm{V}_{1}\right) / \mathrm{V}_{0}=\mathrm{WBC}_{0}$

$\mathrm{WBC}_{1}$ : total number of white blood cells in umbilical cord blood unit with $\mathrm{CPD}$

$\mathrm{V}_{1}$ : total volume of umbilical cord blood unit with $\mathrm{CPD}$

$\mathrm{WBC}_{0}$ : total number of white blood cells in umbilical cord blood unit without $\mathrm{CPD}$

$\mathrm{V}_{0}$ : total volume of collected umbilical cord blood unit without $\mathrm{CPD}$

\section{Blood typing}

Determination of the blood types in the $\mathrm{ABO}$ and $\mathrm{Rh}$ (antigen $\mathrm{D}$ only) blood group systems was carried out in an external laboratorythe Regional Center for Blood Donation and Haemotherapy (Kielce). The material for the tests was a waste resulting from the separation process. It was collected from the waste bag and consisted of red blood cells [5]. The tests were performed with the use of microcolumn gel cards DiaClon AB/O (BIO-RAD, Hercules, CA, USA). 
Citation: Nowakowski P, Laskowski M, Niebudek K, Lorens J, Glenska-Olender J, et al. (2015) Maternal and Neonatal Characteristics of Umbilical Cord Blood Units from the Polish Public Stem Cell Bank of the Regional Science and Technology Center. J Blood Disord Transfus 6: 306. doi:10.4172/2155-9864.1000306

Page 3 of 6

\section{Measurement of CD34+ cell count and percentage}

Total count of CD34+ cells and the percentage of leukocytes $(\mathrm{CD} 45+)$ that are $\mathrm{CD} 34$ positive $(\mathrm{CD} 34+)$ were measured with $\mathrm{BD}$ FACSCalibur flow cytometer (Becton, Dickinson and Company, Franklin Lakes, NJ, USA). Tests were carried out using single-platform method [6] BD Stem Cell Enumeration Kit (Becton, Dickinson and Company, Franklin Lakes, NJ, USA). The kit consisted of:

- antibodies against leukocyte common antigen CD45 conjugated with fluorescein isothiocyanate (FITC),

- antibodies against hematopoietic progenitor cell antigen CD34 conjugated with phycoerythrin (PE),

- fluorescent dye: 7-Aminoactinomycin D (7-AAD) nucleic acid dye for viability measure,

- BD Trucount tubes that allow determining accurate number of CD34+ cells.

Labeling was terminated with lysis of erythrocytes, without washing step, using provided ammonium chloride. Each test required $100 \mu \mathrm{l}$ of undiluted/diluted sample after process of volume reduction. For the data acquisition and analysis the template for BD CellQuest Pro software provided with the kit was used.

\section{Statistical Analysis}

The Kolmogorov-Smirnov test was used for testing the normality of the distribution. The Mann-Whitney $U$ test, the Kruskal-Wallis test, the Student's t-test and Spearman's correlation were used for comparing variables. Differences were considered to be significant when the $\mathrm{p}$ value was less than 0.05 . All statistical calculations were performed using computer software (Statistical Package for the Social Sciences [SPSS], Version 20.0).

\section{Results and Discussion}

\section{Characteristics of neonates and cord blood units}

Maternal and neonatal characteristics of umbilical cord blood units (such as gestational age, birth weight, sex, mode of delivery, $\mathrm{ABO}$ and $\mathrm{RhD}$ blood group of neonates, $\mathrm{WBC}_{0}$ count, CD34+ cell count, percentage of CD34+ cells) are shown in Table 1.

The differences in group counts result from provided data (not every medical record was completely filled) and from type of tests performed on particular blood sample, e.g. blood types in the $\mathrm{ABO}$ and $\mathrm{Rh}$ blood groups system as well as characteristics of cord blood units were determined only for samples which were qualified to the process of preparation (volume reduction) of the umbilical cord blood.

Birth weight, sex, gestational age and mode of delivery were determined according to medical records filled by midwife.

\begin{tabular}{|c|c|c|c|c|c|c|}
\hline Variable & Category & Number & $\%$ & Mean \pm SD & Median & Range \\
\hline \multirow[t]{13}{*}{ Gestational age [weeks] } & & 189 & & $39.30 \pm 1.04$ & 39 & $36.00-42.00$ \\
\hline & 36 & 2 & 1.06 & & & \\
\hline & 36.5 & 1 & 0.53 & & & \\
\hline & 37 & 6 & 3.17 & & & \\
\hline & 37.5 & 1 & 0.53 & & & \\
\hline & 38 & 25 & 13.23 & & & \\
\hline & 38.5 & 8 & 4.23 & & & \\
\hline & 39 & 56 & 29.63 & & & \\
\hline & 39.5 & 5 & 2.65 & & & \\
\hline & 40 & 61 & 32.28 & & & \\
\hline & 40.5 & 11 & 5.82 & & & \\
\hline & 41 & 12 & 6.34 & & & \\
\hline & 42 & 1 & 0.53 & & & \\
\hline \multirow[t]{6}{*}{ Birth weight [kg] } & & 185 & & $3.43 \pm 0.42$ & 3.43 & $2.28-4.48$ \\
\hline & $\leq 2.5$ & 3 & 1.62 & & & \\
\hline & $2.51-3.00$ & 18 & 9.73 & & & \\
\hline & $3.01-3.50$ & 84 & 45.41 & & & \\
\hline & $3.51-4.00$ & 65 & 35.14 & & & \\
\hline & $4.01-4.50$ & 15 & 8.1 & & & \\
\hline
\end{tabular}


Citation: Nowakowski P, Laskowski M, Niebudek K, Lorens J, Glenska-Olender J, et al. (2015) Maternal and Neonatal Characteristics of Umbilical Cord Blood Units from the Polish Public Stem Cell Bank of the Regional Science and Technology Center. J Blood Disord Transfus 6: 306. doi:10.4172/2155-9864.1000306

Page 4 of 6

\begin{tabular}{|c|c|c|c|c|c|c|}
\hline \multirow[t]{3}{*}{ Neonate sex } & & 93 & & & & \\
\hline & Male & 43 & 46.24 & & & \\
\hline & Female & 50 & 53.76 & & & \\
\hline \multirow[t]{3}{*}{ Delivery method } & & 161 & & & & \\
\hline & Vaginal & 105 & 65.22 & & & \\
\hline & Cesarean & 56 & 34.78 & & & \\
\hline \multirow[t]{5}{*}{ ABO blood group of neonates } & & 97 & & & & \\
\hline & 0 & 31 & 31.96 & & & \\
\hline & A & 36 & 37.11 & & & \\
\hline & B & 23 & 23.71 & & & \\
\hline & $A B$ & 7 & 7.22 & & & \\
\hline \multirow[t]{3}{*}{ RhD blood group of neonates } & & 97 & & & & \\
\hline & $\mathrm{RhD}+$ & 79 & 81.44 & & & \\
\hline & RhD- & 18 & 18.56 & & & \\
\hline $\mathrm{WBC}_{0}\left[\times 10^{6} / \mathrm{ml}\right]$ & & 135 & & $15.09 \pm 4.06$ & 14.43 & $6.65-27.15$ \\
\hline CD $34+$ cells $\left[\times 10^{3} / \mathrm{ml}\right]$ & & 99 & & $106.65 \pm 70.53$ & 86.71 & $22.31-343.28$ \\
\hline CD34+ [\%] & & 99 & & $0.30 \pm 0.16$ & 0.26 & $0.02-1.01$ \\
\hline
\end{tabular}

Table 1: Characteristics of neonates and cord blood units.

\section{Effect of sex on birth weight and gestational age of neonates}

Statistical analysis showed that there is correlation between sex and birth weight $(\mathrm{r}=0.273, \mathrm{p}<0.05)$ but differences between body weights of male and female neonates are not statistically significant. Male neonates had insignificantly larger average body weights $(3.63 \pm 0.38$ $\mathrm{kg})$ than female neonates $(3.42 \pm 0.41 \mathrm{~kg})$. Though we conduct our research on small group of samples, our results are in accordance with previous studies [7] conducted on bigger group. Furthermore, relationship between sex and gestational age was examined. There are no statistically significant differences between male and female neonates and gestational age of neonates so there is no influence of sex of neonate on gestational age $(\mathrm{r}=0.066, \mathrm{p}>0.05)$. In our study, the range of gestational age was from 36 to 42 weeks; so it seems to be reasonable to conduct this study on babies born outside this range.

\section{Effect of sex on $\mathrm{WBC}_{0}$ count, CD34+ cell count and percentage of CD34+ cells}

Influence of sex on WBC0 count was examined. Our data suggest that there are no statistically significant relationship between sex and WBC0 number. However, some studies have been reported that sex of neonate could affect WBC count [8]. Statistical analysis showed that there is correlation between sex and CD34+ cell number $(r=0.187$, $\mathrm{p}<0.05)$ as well as between sex and percentage of CD34+ cells $(r=0.229$, $\mathrm{p}<0.05)$. A lot of previous studies reported varying results concerning the effect of neonate sex on the number of CD34+ cells [7-10] and some of them have shown there is no correlation between these factors. In our study, male neonates had larger percentage of CD34+ cells than female neonates $(0.35 \pm 0.18 \%$ vs. $0.28 \pm 0.15 \%)$. Comparison is shown in Figure 2. This data suggest that cord blood units should not be selected with regard to sex of neonate, however it is necessary to carry out this research on larger population. Furthermore, we have to examine correlation between CD34+ cell count and total nucleated cell count (TNC) to compare our results with those obtained by other scientists.

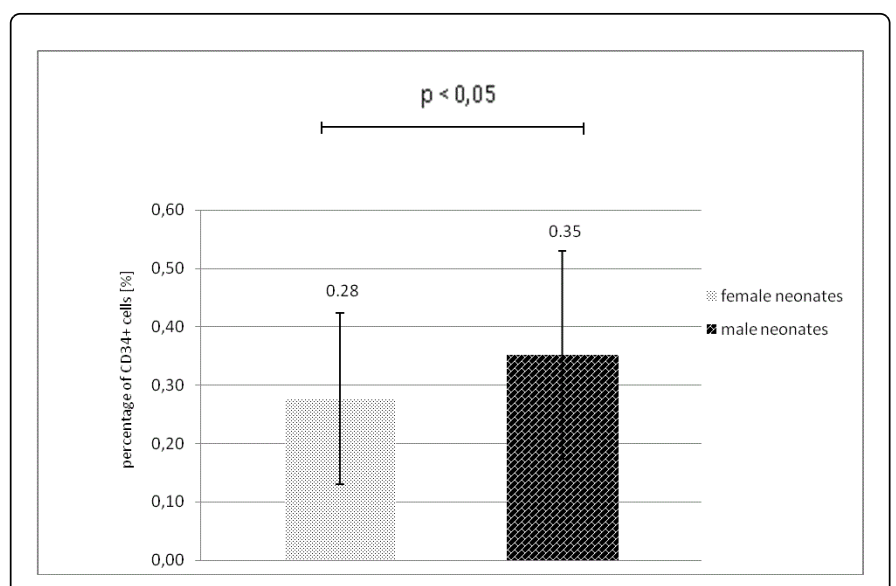

Figure 2: Effect of sex on percentage of CD34+ cells.

\section{Effect of gestational age on mode of delivery}

Statistical analysis showed that there is no correlation between gestational age and mode of delivery $(r=0.095, \mathrm{p}<0.05)$. The statistics in 
Citation: Nowakowski P, Laskowski M, Niebudek K, Lorens J, Glenska-Olender J, et al. (2015) Maternal and Neonatal Characteristics of Umbilical Cord Blood Units from the Polish Public Stem Cell Bank of the Regional Science and Technology Center. J Blood Disord Transfus 6: 306. doi:10.4172/2155-9864.1000306

Page 5 of 6

Poland show that the number of cesarean sections is increasing, moreover it is not always caused by medical factors. In 2011, almost 300 in 1000 births were performed via cesarean section [11]. According to data obtained in our study, no significant differences between the number of caesarean sections and natural births depending on the age of pregnancy were observed. The medical reports provided for each cord blood sample did not have any comments on the reasons for caesarean section. It would be appropriate to include this information in the reports for future samples. We cannot assume that gestational age in the case of our study had an influence on the mode of delivery.

\section{Effect of gestational age on $\mathrm{WBC}_{0}$ count, $\mathrm{CD} 34+$ cell count and percentage of $\mathrm{CD} 34+$ cells}

Statistical analysis showed that there is no correlation between gestational age and $\mathrm{WBC}_{0}$ count $(\mathrm{r}=0.13, \mathrm{p}<0.05)$ and there is no correlation between gestational age and percentage of CD34+ cells $(\mathrm{r}=-0.142, \mathrm{p}<0.05)$. Comparison is shown in Figure 3.

In our study WBC counts were obtained at the same level. The study shows that the total number of CD34+ cells is inversely related to gestational age. The highest total number of CD34+ cells was reported for 36-week of pregnancy. Similar conclusions were reached by Canabaro group et al. and Gasparoni group et al. [12,13].

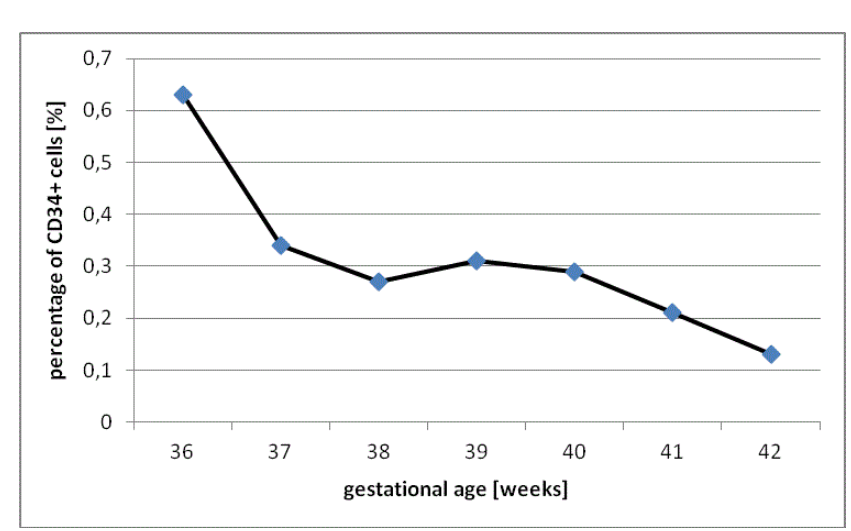

Figure 3: Effect of gestational age on percentage of CD34+ cells.

\section{Effect of $\mathrm{ABO}$ and $\mathrm{RhD}$ blood type of neonates on $\mathrm{WBC}_{0}$ count}

Currently, most research is focused on the correlation between blood type and TNC count of cord blood unit. Influence of ABO blood group on the total white blood cell count in the umbilical cord blood unit without CPD was examined. According to our study, there is no statistically significant correlation between these two variables $(\mathrm{r}=0.049, \mathrm{p}>0.05)$.

This result is consistent with results for TNC, carried out by other scientists [14]. We can conclude that $\mathrm{ABO}$ blood system does not influence TNC or WBC count. The influence of $\mathrm{RhD}$ factor on $\mathrm{WBC}_{0}$ count was examined. Also in this case statistical analysis did not show statistically significant correlation between these two variables $(\mathrm{r}=0.033, \mathrm{p}>0.05)$.

\section{Effect of $\mathrm{ABO}$ and $\mathrm{RhD}$ blood type of neonates on CD34+ cell count and percentage of CD34+ cells}

The effect of the $\mathrm{ABO}$ and $\mathrm{RhD}$ blood type on the number of CD34+ and percentage of CD34+ cells was examined. A total number of stem cells in the material depends on factors such as: volume of collected umbilical cord blood (variable volume of UCB, constant volume of $\mathrm{CPD}$ ) and the effectiveness of the process of volume reduction. In our opinion, in order to examine influence of blood type on CD34+ cell count circulating in blood of the umbilical cord it is necessary to determine a percentage of CD34+ cells, and not a total count of those cells as it depends on the abovementioned factors. However, no statistically significant differences were observed between blood types in total count and percentage of CD34+ cells. The correlation coefficients between $\mathrm{ABO}$ blood type and the total CD34+ count as well as between $\mathrm{ABO}$ blood type and the percentage of CD34+ cells were respectively: $r=-0.111, p>0.05$, and $r=-0.102$, $\mathrm{p}>0.168$. The correlation coefficients between Rh blood type and the total CD34+ count, as well as between Rh blood type and percentage of CD34+ cells were respectively $\mathrm{r}=-0.026, \mathrm{p}>0.05$, and $\mathrm{r}=-0.164, \mathrm{p}>0.168$.

Our data suggest that expression of blood type antigens, such as A, $B, H, D$, on the surface of red blood cells, has no effect on the total number of white blood cells and hematopoietic stem cells circulating in the umbilical cord blood.

\section{Conclusion}

In our studies we decided to study the effects of maternal and neonatal factors on umbilical cord blood units. Positive correlation between sex of the neonate and birth weight was reported. Our results suggest that sex/blood group typing is not useful for assessing whether future collected umbilical cord blood will possess greater or lower therapeutic potential [15], however it is necessary to perform the studies on larger population.

\section{Acknowledgments}

Forming the Public Stem Cell Bank of The Regional Science and Technology Center is a result of implementation of the project: "Establishment of a Bank for Stem Cells in the Swietokrzyskie Voivodeship as an Opportunity to implement new Scientific-Research Methods Regarding Medicine and Transplantology". Bank's actions are funded from the budget resources of the Swietokrzyskie Voivodeship.

We appreciate the contribution of Polish mothers who voluntarily donate cord blood to the Public Stem Cell Bank of The Regional Science and Technology Center in Podzamcze.

\section{References}

1. Li K, Liu J, Fok TF, Yau FW, Wong A, et al. (1999) Human neonatal blood: stem cell content, kinetics of CD34+ cell decline and ex vivo expansion capacity. Br J Haematol 104: 178-185.

2. Wagner JE1 (1994) Umbilical cord blood transplantation: overview of the clinical experience. Blood Cells 20: 227-233.

3. Rabinovitch A (2009) Cord Blood Hematology. Lab. Med 40: 629.

4. Katsares V, Paraidis Z, Nikolaidou E, Karvounidou I, Ardelean KA, et al. (2009) Reference ranges for umbilical cord blood hematological values. Lab Med 40: 437-439.

5. M-Reboredo N, Díaz A, Castro A, Villaescusa RG (2000) Collection, processing and cryopreservation of umbilical cord blood for unrelated transplantation. Bone Marrow Transplant 26: 1263-1270. 
Citation: Nowakowski P, Laskowski M, Niebudek K, Lorens J, Glenska-Olender J, et al. (2015) Maternal and Neonatal Characteristics of Umbilical Cord Blood Units from the Polish Public Stem Cell Bank of the Regional Science and Technology Center. J Blood Disord Transfus 6: 306. doi:10.4172/2155-9864.1000306

Page 6 of 6

6. Barnett D, Granger V, Whitby L, Storie I, Reilly JT (1999) Absolute CD4+ T-lymphocyte and CD34+ stem cell counts by single-platform flow cytometry: the way forward. Br J Haematol 106: 1059-1062.

7. Lee HR, Park JS, Shin S, Roh EY, Yoon JH, et al. (2011) Increased numbers of total nucleated CD34+ cells in blood group 0 cord blood: an analysis of neonatal innate factors in the Korean population. Transfusion 52: 76-81.

8. Chang YH, Yang SH, Wang TF, Lin TY, Yang KL, et al. (2011) Complete blood count reference values of cord blood in Taiwan and the influence of gender and delivery route on them. Pediatr Neonatol $52: 155-160$.

9. Ballen KK, Wilson M, Wuu J, Ceredona AM, Hsieh C, et al. (2001) Bigger is better: maternal and neonatal predictors of hematopoietic potential of umbilical cord blood units. Bone Marrow Transplant 27: 7-14.

10. Mancinelli F, Tamburini A, Spagnoli A, Malerba C, Suppo G, et al. (2006) Optimizing umbilical cord blood collection: impact of obstetric factors versus quality of cord blood units. Transplant Proc 38: 1174-1176.
11. Malesa E, Koehne N, Koziski M, Krol E, Lewandowska O, et al. (2013) Health and health care in 2012. Statistical Publishing Establishment.

12. Canabarro R, Sporleder H, Gomes T, Zanatta G, Scribel L, et al. (2007) Immunophenotypic evaluation, and physiological and laboratory correlations of hematopoietic stem cells from umbilical cord blood. Biocell 31: 397-403.

13. Gasparoni A, Ciardelli L, Avanzini MA, Bonfichi M, Mario M, et. al (2000) Immunophenotypic changes of fetal cord blood hematopoietic progenitor cells during gestation. Pediatr Res. 47: 825-829.

14. Perez F, Vazquez A, Rodriguez D, Sanchez E, Solis E (2012) Impact of some neonatal factors on the quality of cord blood units (CBU) in the Mexican Altruistic Cord Blood Bank-Bacecu. Human Immunology 73: 120 .

15. Urbano-Ispizua A (2003) High stem cell dose in haemopoietic transplantation: is it always beneficial? Leukemia 17: 1467-1469. 